\title{
СУТНІСТЬ ТА СКЛАДОВІ ЦИФРОВОГО ІНТЕДЕКТУ ОСОБИСТОСТІ
}

У статті висвітлено сутність на складові изифрового інтелекту особистості, який значною мірою визначае ефективність діяльності людини в сучасному світі.

Зауважено, що нині циифровий інтелект для людини є необхіністю, оскільки сучасні моделі навчання стають ефективними тільки за умови достатнього рівня оволодіння цุифровими технологіями всіма учасниками освітнього процесу та уміння побудувати ефективні взаємовідносини у ицифровому просторі. Висвітлено сутність циифрового інтелекту (DQ), його складових (ц̧ифрова пам'ять, цุифрова емпатія, цุифровий слід) та їх місице всучасному освітньому середовищі. Наголошено, щз процес циифровізацій суспільства безпосередньо впливає на набір компетенцій, які необхінні сучасному спеціалісту. Цей набір компетенцій динамічно змінюеться паралельно змінам в економіці.

Розкрито поняття циифрової емпатії та ії значення в організації освітнього процесу в умовах онлайн-навчання. Вказано, що прояв емпатї̈ в онлайн-середовищі складніший, ніж при очному спіккуванні.

Описано деякі стратегї, які допомагають спікеру-викладачу викликати емоциї онлайн: відчуття та розуміння цільвової аудиторії, інструктаж учнів щодо способів опанування навчального матеріалу, кольори, емодзі, слова, підтримання регулярного онлайн-зв'язку, взаемодія в чаті, активне слухання.

Наголошено, щз з изифровою емпатією пов'язано поняття ицифрової емоційної пам'яті, оскільки опанування інформаційно-цицрових технологій супроводжуеться значною емоційною забарвленістю. Розкрито поняття «цุифрового сліду» як інформації, яка залишається внаслідок роботи користувача в мережі, а також «цифрових спогадів», щзо засновані на емоційному контакті з ицфровими об'єктами та сприяють підвищенню мотивацій навчання за рахунок створення ситуацї̈ успіху.

Зроблено висновок, щяо в умовах глобальної циифровізації сучасного світу наявність розвиненого изифрового інтелекту та його складових є необхідністю для кожної особистості, азагальна формула сучасної успішної особистості - цзе гармонійне поєднання когнітивного, емоційного та циифрового інтелектів.

Ключові слова: ццифровий інтелект особистості, цุифрова пал'ять, цุифрова емпатія, цุифровий слід, цุифрові компетенції, цุифровізація освіти.

Постановка проблеми. Сьогодні в умовах, коди інформаційно-цифрові технології стали невід'ємною частиною життя сучасного суспільства, метою цифрової економіки в освіті є надання інформаційних послуг споживачам; виробництво інформаційної продукції, а саме бази знань та інформаційних технологій.

Розвиток технологій та скорочення життєвого циклу професій призвело до «старіння» деяких професій, до деактуалізації класичної моделі освіти. На заміну йй прийшла концепція неперервної освіти впродовж життя (lifelong learning) [1]. Саме тому актуальним є формування у молодого покоління когнітивного інтелекту. Він допомагає вчитися, застосовуючи для цього різні техніки й інструменти, використовувати знання на практиці, робить здобувачів освіти більш ефективними й успішними.

\footnotetext{
*C) Кохановська О. В.
} 
Маємо визнати, що сьогодні на інтенсивність використання інформаційноцифрових технологій значно вплинула пандемія COVID-19. Цей уплив здебільшого є позитивним. Зокрема, відмічається значне підвищення рівня цифрової (digital) грамотності суспільства, окреслюються нові шляхи та напрямки digital-співробітництва у всіх сферах діяльності, зокрема в освіті.

Це потребує формування у суспільства зовсім нового виду інтелекту - цифрового (digital).

Ще нещодавно вважалося, що інтелект у людини один, і кожна людина або його має, або ні. Нині психологи, які досліджують людський мозок, виділяють до 35 видів інтелекту, кожен з яких може бути розвинений у конкретного індивіда тією чи іншою мірою. Крім того, кожна людина здатна до керованого розвитку, а різні види інтелекту разом (у системі) розвиваються краще, посидюючи один одного [7]. Наявність у людини цифрового інтелекту сьогодні $е$ необхідністю, адже сучасні моделі змішаного, перевернутого, дистанційного навчання можуть стати ефективними тільки тоді, коди всі учасники освітнього процесу матимуть достатній рівень володіння цифровими технологіями та умінням взаємодіяти у цифровому просторі.

Тому питання розвитку цифрового інтелекту та його складових в освіті є актуальним і сучасним.

Аналіз досліджень. Застосування цифрових технологій в освіті є предметом дослідження багатьох сучасних науковців, серед яких варто відмітити таких українських учених: В. Биков, А. Гуржій, М. Жалдак, В. Олійник, О. Спірін та ін. Питання цифрового інтелекту (DQ) та його розвитку стало предметом дослідження Д. Богданової, М. Ріббі, В. Беннета, М. Парка та ін. Емоційний інтелект у цифрову епоху розглядав Д. Гоулман.

Мета статті - висвітдити сутність digital-інтелекту, його складові (цифрова пам'ять, цифрова емпатія, цифровий слід) та їх місце в сучасному освітньому середовищі.

Викдад основного матеріалу. Загадьновідомо, що для успішного навчання важливе значення має коефіцієнт рівня інтелекту (IQ). Він є показником розумових здібностей людини (коефіцієнт розумового розвитку). У більш вузькому розумінні IQ це співвідношення так званого «розумового віку» до справжнього «хронологічного віку» певної особистості (індивіда).

В 90-х роках XX століття з'явилось інше поняття - «емоційний інтелект» (EQ), яке описує здатність дюдини пізнавати власні емоції та виявдяти емпатію до інших.

За визначенням Д. Карузо, Дж. Майєра, П. Селовея, емоційний інтелект - група ментальних здібностей, які викликають визнання і розуміння власних емоцій та емоцій оточуючих [3].

Виділяють чотири основні складові емоційного інтелекту: самосвідомість, самоконтроль, емпатія, навички міжособистісних взаємовідносин. Д. Гоулман, окрім вищеперерахованого, виділяе також мотивацію як складову емоційного інтелекту [там само].

3 емоційним інтелектом пов'язані необхідні сучасному поколінню «м'які навички» (soft skills) - комунікація, лідерство, прийняття рішень, співчуття, командна робота та ін.), а також уміння користуватися цифровими технологіями 3 метою підвищення ефективності виробничого або освітнього процесу (digital dexterity). Найбільшим попитом на ринку праці сьогодні користуються спеціалісти, які не лише вододіють цифровою грамотністю, а й здатні пристосовуватися до цифрового середовища, мають навички користування сучасними цифровими методиками [5].

Набір компетенцій, необхідних сучасному спеціалісту, вже давно перестав бути статичним та фіксованим, він змінюеться паралельно змінам економіки, утворюючи «динамічний портфель». До цього переліку, зокрема, входять такі поняття: «цифровий інтелект» та його складові - «цифрова емпатія», «цифрова пам'ять», «цифровий слід» та ін. [там само]. 
Швидкий розвиток цифрових технологій задав нові умови для життя. Все частіше можна почути такі слова, як: «невідомість», «міндивість», «неоднозначність», «лавиноподібний потік інформації». Уміння працювати 3 цією частиною реальності, здатність мислити та приймати рішення в умовах невідомості, вибудовувати мережеву комунікацію за рамками або крізь вікові, культурні та географічні межі, розширювати можливості фізичного світу за рахунок віртуального - це те, що можна назвати digitalінтелектом (DQ (digital intelligence) - цифровий інтелект). Саме цей вид інтелекту значною мірою визначає ефективність Аюдини в сучасному світі [10].

Уперше показник DQ було використано у 2014 році Міністерством зв'язку Великої Британії, яке опублікувало результати щорічного маркетингового дослідження. У звіті під DQ розуміли коефіцієнт цифрової впевненості, який відображав рівень умінь користувачів. Тоді найвищий рівень цього коефіцієнту був притаманний дітям 14-15 років, а значення коефіцієнту для дітей 6 та осіб 45 років було однаковим, що свідчило про однакові уміння цих категорій щодо користування сервісами та додатками [14].

Єдиний дослідницький центр JRC (JRC - Joint Research Centre) Європейської комісії 3 науки та освіти у 2017 році запропонував розробку, присвячену навчанню та формуванню навичок для цифрової ери. Метою цієї розробки була допомога державам Євросоюзу у підвищенні цифрової грамотності населення та використання потенціалу цифрових технологій, зокрема для впровадження їх в освітню практику. Розробники запропонували єдину структуру навчання цифровим навичкам і компетентностям, які необхідні для розвитку та соціальної інтеграції (рис. 1).



Pис. 1. Компетенції DQ [15] 
Саме ця розробка стала ключовою для активізації ініціатив держав світу щодо розвитку цифрового інтелекту. У 2017 році опубліковано програму DigComp 2.1 - систему цифрових компетенцій, яку пропонується використовувати як для навчання, так і при прийомі на роботу. У такий спосіб окреслено вектор розвитку цифрових навичок суспільства [2, с. 7].

Як бачимо на рисунку 1, DigComp 2.1 є тривимірною таксономією, базовий рівень якої включає п'ять компетенцій, які охоплюють 24 рубрики, 8 рівнів кваліфікації: цифрова ідентичність, цифрові права, цифрова грамотність, використання цифрових технологій, цифрові технології, комунікація, цифрова безпека, цифровий емоційний інтелект.

С. Умнов виділяе три рівні цифрового інтелекту: 1) digital-мислення (полягає в умінні виокремлення інформації з потоку, оцінювання адекватності джерела); 2) digitalкомунікація (уміння вибудовувати мережі соціальних контактів, взаємодіяти у новому форматі); 3) digital-розвиток (здатність постійно навчатися в онлайн-середовищі) [15].

Виділяють три базових рівня зрілості цифрового інтелекту:

- цифрове громадянство - здатність використовувати цифрові технології та медіа безпечно, відповідально та ефективно;

- цифрова креативність - здатність стати частиною цифрової екосистеми шляхом створення нового контенту та втілення ідеї в реальність за допомогою цифрових інструментів;

- цифрове підприємництво - здатність використовувати цифрові технології і медіа для розв'язування глобальних проблем та вирішення нових завдань [12].

Однією $з$ найважливіших складових цифрового інтелекту є наявність цифрового емоційного інтелекту, складовою якого є цифрова емпатія (digital-емпатія).

Digital-емпатія - нова концепція, спрямована на виділення соціальних, емоційних, когнітивних практик у спільній груповій роботі в рамках проєктної діяльності, цифрової та медіаграмотності. Сам термін має кілька значень. 3 одного боку, це використання основних принципів емпатії - співчуття, емоцій - при розробці сучасних IT-технологій для покращення взаємодії в системах «людина - машина», «людина - машина - інтелект» (онлайн спілкування з використанням гаджетів). 3 іншого - цифрову емпатію розуміють як когнітивну та емоційну здатність до рефлексії і соціадьної відповідальності при стратегічному використанні цифрових медіа [8].

В умовах пануючого нині дистанційного та змішаного навчання, зокрема в школах України, у кожного педагога під час онлайн взаємодії виникає ряд питань, які пов'язані з цифровою емпатією, серед яких наступні:

1. Як продемонструвати емоції онлайн та чи будуть вони зрозумілі співрозмовникам?

2. Чи можлива емпатія поза реальним спілкуванням?

3. Як під час комунікації онлайн викдикати відчуття контакту, тепла, людяності?

Усі ці запитання пов'язані з особливостями онлайн навчання та спілкування, адже важливою частиною ефективної онлайн-взаємодії є встановлення оберненої взаємодії спікера з учасниками.

Прояв онлайн-емпатії складніший, ніж при очному спілкуванні, тому варто вчитися передаванню емоцій онлайн.

Існує кілька стратегій, які допомагають спікеру-викладачу виявляти свої емоції онлайн [13].

1. Відчуття та розуміння цุільової аудиторії. Такий ефект досягається за допомогою опитувань, тестів, анкет, які доцільно використовувати на різних етапах занять. Вони допомагають відстежити зацікавленість аудиторії, розуміння матеріалу, зацікавленість та iн.

2. Інструктування учнів щодо опанування навчального матеріалу. Віддаленість спілкування передбачає поради щодо опанування матеріалу курсу, додаткових ресурсів, 
самодисципліни, тайм-менеджменту, спілкування. Така взаємодія доводить зацікавленість викладача в успішному навчанні аудиторії.

3. Кольори. Допомагають передати власну палітру емоцій, викдикати певні почуття у здобувачів освіти, адже, впливаючи на мозок, вони впливають і на почуття.

4. Емодзі. Є одним з найефективніших інструментів впливу на аудиторію. Можна використовувати як фото июдей, на обличчі яких виражено певну палітру емоцій, так і фон з відповідним зображенням, яке має викликати певні відчуття (камін - затишок, клас - навчання, зосередженість та ін.).

5. Слова. Треба використовувати потужні дієслова для передачі емоцій та їх оживлення у сприйнятті учнів.

6. Підтримання регулярного онлайн-зв'язку. Ця вимога є необхідним проявом емпатії, що переконуе у зацікавленості викладача в найкращих результатах здобувачів освіти. Такий зв'язок можна організовувати засобами відеочату, иистування в месенджері, повідомлень на поштові скриньки тощо.

7. Взаємодія в чаті. В чатах учасники мають змогу виявити свої думки, очікування, поставити запитання. Такі прояви не можна ігнорувати, а, навпаки, завжди звертати увагу на чат, надаючи учасникам змогу проявити себе.

8. Активне слухання. Активне слухання спікера дозволяе учасникам освітнього процесу виявити власні емоції та сприяє проявам емпатії. Головне - виявляти повагу до позиції та почуттів учасників.

Дотримуючись основних вимог, спілкування як в онлайн, так і в оффлайн форматах може бути ефективним та емпатичним.

3 цифровою емпатією тісно пов'язане поняття «емоційна цифрова пам'ять» - це спогади про переживання, які викликали емоційну реакцію. Найбільш часто воно використовується для позначення здатності свідомо пам'ятати аспекти цифрового досвіду. По-іншому, цей термін використовується для опису ефектів емоцій в епізодичній пам'яті.

Емоційна пам'ять - це психічні процеси, які характеризуються запам'ятовуванням емоцій та їх наступним відтворенням. Фактично це пам'ять на переживання. Вона бере участь у всіх видах пам'яті, але особливо проявляеться у июдських взаєминах. Завдяки емоційній пам'яті відбувається міцне запам'ятовування матеріалу, який вивчається. Відомо, те, що у людини викликає емоційні переживання, запам'ятовуеться нею без особливих зусиль та на більш довгий строк [9, с. 36].

У деяких джерелах зазначено, що цифрова пам'ять є явищем, яке характеризує феномен збереження інформації в умовах цифрового середовища. Переважна кількість досліджень цифрової пам'яті спрямована на виявлення наслідків впливу мережі Інтернет на користувача, як за життя, так і після нього. Дослідженням цифрової пам'яті займаються представники наукового напряму Digital Memory Studies [11].

При пануванні онлайн та змішаного навчання інформація, яка подається викладачем для сприйняття здобувачами освіти, має бути емоційною. Така інформація ближча до порогу зчитування і задишае у пам'яті відповідний відбиток, що надалі сприяе іï запам' ятовуванню [11, с. 42].

Опанування інформаційно-цифрових технологій зазвичай супроводжується значною емоційною забарвленістю, адже сучасне мододе покоління виросло серед «клацання телевізійним пультом» та стрічок новин. Молодь може швидко сприймати та обробляти великі обсяги інформації, оперативно реагувати на нові повідомлення.

Особливість цифрових засобів, яких на сьогодні є значна кількість, полягає в тому, що вони істотно полегшують розуміння та запам'ятовування найбільш важливих понять та прикладів, залучають здобувачів освіти в процес навчання, викдикаючи при цьому позитивні емоції та створюючи ситуацію успіху. Тому викладач повинен забезпечити глибоке, яскраве, точне враження про те, що необхідно запам'ятати. Адже про ситуації, які залишили в нашій пам'яті яскравий слід, люди думають більше, ніж про емоційно 
нейтральні події. При цьому позитивні емоції, як правило, сприяють фіксації їх у пам'яті, а негативні - ні [11].

Варто акцентувати, що навчання стає різко неефективним за низької емоційної забарвленості навчальної інформації.

Оскільки мережа Інтернет - це всесвітня павутина та велика база даних, то будь-які користувачі, які працюють в мережі, залишають у ній «цифрові сліди». Це можуть бути відео-, текстові записи, зображення, інтернет-акаунти на різних сайтах та ін. Відмітимо, що поняття «цифрова пам'ять» на відміну від «цифрового сліду» характеризує не самі «відбитки», які залишила конкретна людина, а те, що з ними відбувається через тиждень, місяць, рік, 5, 10, 15 років, i, навіть, після смерті того, хто їх залишив. Тому доцільно розкривати здобувачам освіти сутність поняття «цифрові сліди», інформацію, яку можна відстежити за цими «слідами» та управління ними в мережі.

Під час спільної роботи в мережі, виконання освітніх проєктів формуються «цифрові спогади», засновані на емоційному контакті з цифровими об'єктами - засобами цифрової дидактики (частини загальної дидактики, основним предметом дослідження якої є система навчання в умовах глобальної цифровізації, а засобами - цифрові педагогічні технологї̈, метацифрові комплекси та ресурси персоналізації освітнього процесу).

Цифрові спогади формують певні рівні розуміння щодо об'єктів, утворюючи певні розумові зв'язки. Один і той самий об'єкт може бути тригером (спусковим гачком, який викликає певні емоції) більш, ніж на одному рівні.

Якісна освіта в рамках цифрового громадянства має обов'язково передбачати зворотній зв'язок (фідбек) та оцінки. При цьому оцінювання має бути адаптивним та всебічним, щоб оцінити комплексно навички цифрового інтелекту. А наприкінці має бути забезпечений фідбек, що зможе показати як учителю, так і учням слабкі та сильні сторони отриманих знань та вибудувати кожному здобувачу освіти власну траєкторію успіху. Крім того, суспільство має зрозуміти важдивість цифрового громадянства, що є основою національного цифрового інтелекту, і зробити його пріоритетом сучасної освіти.

Тим більше, що сьогодні в усьому світі (зокрема, в Україні) відбувається процес стрімкої цифровізації освіти. К. Краус у своєму дослідженні зазначає, що цифрова освіта здійснюеться засобами цифрових технологій, що суттево впливає на вже існуючу традиційну систему і трансформує іiі. Це відбуваеться за рахунок використання різноманітних електронних ресурсів, збільшення кількості віртуальних освітніх платформ. Кінцевою метою такої трансформації виступає розширення кількості та змісту освітніх послуг, а також запровадження нових інноваційних технологій, цифрових платформ формальної та неформальної освіти [4, с. 262; 6, с. 49].

Висновки. Результати дослідження доводять, що в умовах глобальної цифровізації сучасного світу наявність розвиненого цифрового інтелекту та його складових є необхідністю дия кожної особистості. Можна стверджувати, що загальна формула сучасної успішної особистості це IQ + EQ + DQ. Кожна складова цієї формули не може дорівнювати нулю і є обов' язковою для сучасної людини. Цифрові навички (digital skills) стали основою досягнення успіху молодим поколінням. Тому їх формування є завданням системи освіти.

Зростання цифровізації освіти та застосування різноманітних моделей іiі реалізації сьогодні (змішане, дистанційне, перевернуте навчання та ін.) вимагає врахування всіх складових цифрового інтелекту в процесі навчання. Цей процес покладено на викладача як основного рушія та агента сучасних реформ. Саме він, чітко усвідомлюючи всі складові цифрового інтелекту, має вдало підібрати ті форми, методи та засоби навчання, які сприятимуть якнайкращому засвоєнню здобувачами освіти навчального матеріалу.

Перспективи подальших досліджень полягатимуть у виокремленні найбільш ефективних форм, методів і засобів формування цифрового інтелекту у здобувачів освіти. 


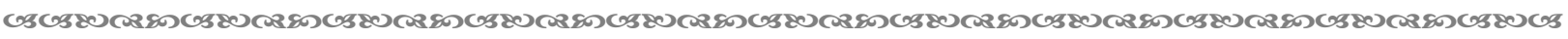
ПЕДАГОГИНИЙ АЛЬМАНАХ. - 2020. - ВИПУСК 46

U3

\section{Список використаних джерел:}

1. Абрамов А. Непрерывное обучение как главный тренд образования будущего. URL: https://trends.rbc.ru/trends/education/5eb9cc339a79471380ca55f9

2. Богданова Д. А. Обучение навыкам дия цифровой эры: современный ландшафт. Педагогика информатики. 2020; 2. URL: https://pcs.bsu.by/2020 2/1ru.pdf

3. Гоулман Д. Эмоциональный интеллект. М. : АСТ, 2010. 476 с.

4. Зубко А. М., Жорова І. Я., Кузьменко В. В., Слюсаренко Н. В., Кохановська О.В. Інформаційнокомунікаційні технології як чинник розвитку професіоналізму педагогів у системі післядипломної освіти. Інформаціийні технологї̈ і засоби навчання. 2020. Том 77. № 3. С. 262-281. URL: https://journal.iitta.gov.ua/index.php/itlt/article/view/3562

5. Компетенции в эпоху цифровизации. URL: https://premiummanagement.com/blog/kompetenciiv-jepohu-cifrovizacii

6. Рік особистої ефективності. Збірник 1: Когнітивний інтелект. Ефективно вчуся, використовую техніки й інструменти. URL: https://kniga.biz.ua/book-rik-osobistoi-efektivnosti-zbirnik-1kognitivnii-intelekt-efektivno-vchusia-vikoristovuiu-tekhniki-i-instrumenti-0026334.html

7. Краус К. М. Імперативи формування цифрової освіти в Україні. Управління соиіальноекономічними трансформаціями у сучасному місті: матеріали Всеукраїнської науковопрактичної конференції (27 лютого 2018 року). Київ: КУБГ, 2018. С. 49-51.

8. Руслякова Е. Е., Тимофеева Э. А., Шестакова Ю. В., Чепайкин Д. А. Исследование уровня эмпатии у подростков, увлечённых компьютерными технологиями. Цифровая эмпатия. Мир науки. Педагогика и психология. 2020. № 6, URL: https://mir-nauki.com/PDF/20PSMN620.pdf

9. Стариченко Б. Е. Методика использования информационно-коммуникационных технологий в учебном процессе. Ч. 1. Концептуальные основы компьютерной дидактики: учебное пособие / Урал. гос. пед. ун-т. Екатеринбург, 2013. 139 с.

10. Умнов C. Зачем успешному человеку нужен digital-интеллект. URL: https://www.vedomosti.ru/management/articles/2014/07/16/intellekt-novejshego-vremeni

11. Цифровая память. Материал из Википедии - свободной энциклопедии. URL: https://ru.wikipedia.org/wiki/\%D0\%A6\%D0\%B8\%D1\%84\%D1\%80\%D0\%BE\%D0\%B2\%D0\%B0\%D1 \%8F \%D0\%BF\%D0\%B0\%D0\%BC\%D1\%8F\%D1\%82\%D1\%8C\#: :text=\%D0\%A6\%D0\%B8\%D1\%84\%D 1\%80\%D0\%BE\%D0\%B2\%D0\%B0\%D1\%8F\%20\%D0\%BF\%D0\%B0\%D0\%BC\%D1\%8F\%D1\%82\%D1\%8 C\%20\%D0\%B0\%D0\%BD\%D0\%B3\%D0\%BB.,\%D0\%B6\%D0\%B8\%D0\%B7\%D0\%BD\%D0\%B8\%2C\%2 0\%D1\%82\%D0\%B0\%D0\%BA\%20\%D0\%B8\%20\%D0\%BF\%D0\%BE\%D1\%81\%D0\%BB\%D0\%B5\%20\% D0\%BD\%D0\%B5\%D0\%B5.

12. Цифровой интеллект: 8 digital-навыков, которые пригодятся современному поколению детей. URL: $\quad$ https://womo.ua/tsifrovoy-intellekt-8-digital-navyikov-kotoryie-prigodyatsyasovremennomu-pokoleniyu-detey/

13. Як виявляти емпатію в навчальному онлайн-середовищі? URL: http://osnova.com.ua/news/1903\%D0\%AF\%D0\%BA \%D0\%B2\%D0\%B8\%D1\%8F\%D0\%B2\%D0\%BB\%D1\%8F\%D1\%82\%D0\%B8 \%D0 \%B5\%D0\%BC\%D0\%BF\%D0\%B0\%D1\%82\%D1\%96\%D1\%8E \%D0\%B2 \%D0\%BD\%D0\%B0\%D0\%B2 \%D1\%87\%D0\%B0\%D0\%BB\%D1\%8C\%D0\%BD\%D0\%BE\%D0\%BC\%D1\%83 \%D0\%BE\%D0\%BD\%D0 $\% \mathrm{BB} \% \mathrm{D} 0 \% \mathrm{~B} 0 \% \mathrm{D} 0 \% \mathrm{~B} 9 \% \mathrm{D} 0 \% \mathrm{BD}-$

\%D1\%81\%D0\%B5\%D1\%80\%D0\%B5\%D0\%B4\%D0\%BE\%D0\%B2\%D0\%B8\%D1\%89\%D1\%96\%3F

14. Bogdanova, D., Berezina, N. Opyt formirovaniya tsifrovor̃ i mediagramotnosti: na puti k tsifrovomu grazhdanstvu [The experience of digital and media literacy: on the path to digital citizenship]. Konferentsiya IITE2014. Moskva [IITE2014 Conference, Moscow]. 2014. October, 14-15. (In Russian).

15. DQ Institute. Leading Digital Education, Culture and Innovation. URL: https://www.dqinstitute.org/

\section{References:}

1. Abramov, A. Nepreryvnoe obuchenie kak glavnyi trend obrazovaniia budushchego [Lifelong learning as the main trend in the education of the future]. Retrieved from https://trends.rbc.ru/trends/education/5eb9cc339a79471380ca55f9 [in Russian].

2. Bogdanova, D. A. (2020). Obuchenie navykam dlia tcifrovoi ery: sovremennyi landshaft [Learning skills for the digital era: the modern landscape]. Pedagogika informatiki, 2. Retrieved from https://pcs.bsu.by/2020 2/1ru.pdf [in Russian].

3. Goulman, D. (2010). Emotcionalnyi intellekt [Emotional intellect]. Moskva: AST [in Russian]. 
Us ПЕДАГОГІЧНИЙ АЛЬМАНАХ. - 2020. - ВИПУСК 46

U3

4. Zubko, A., Zhorova, I., Kuzmenko, V., Slyusarenko, N., \& Kokhanovska, O. (2020). Informatsiinokomunikatsiini tekhnolohii yak chynnyk rozvytku profesionalizmu pedahohiv u systemi pisliadyplomnoi osvity [Information and communication technologies as a factor of teachers' professionalism development in the system of postgraduate education]. Informatsiini tekhnolohii izasoby navchannia, $77(3), \quad 262-281 . \quad$ Retrieved from https://journal.iitta.gov.ua/index.php/itlt/article/view/3562 [in Ukrainian].

5. Kompetentcii $\mathrm{v}$ epokhu tcifrovizatcii [Competencies in the digital age]. Retrieved from https://premiummanagement.com/blog/kompetencii-v-jepohu-cifrovizacii [in Russian].

6. Rik osobystoi efektyvnosti [Year of personal effectiveness]. In Kohnityvnyi intelekt. Efektyvno vchusia, vykorystovuiu tekhniky y instrumenty [Cognitive intelligence. I study effectively, use techniques and tools]. Retrieved from https://kniga.biz.ua/book-rik-osobistoi-efektivnosti-zbirnik-1-kognitivniiintelekt-efektivno-vchusia-vikoristovuiu-tekhniki-i-instrumenti-0026334.html [in Ukrainian].

7. Kraus, K. M. (2018). Imperatyvy formuvannia tsyfrovoi osvity $v$ Ukraini [Imperatives of digital education formation in Ukraine], Upravlinnia sotsialno-ekonomichnymy transformatsiiamy u suchasnomu misti: materialy Vseukrainskoi naukovo-praktychnoi konferentsii [Management of socio-economic transformations in the modern city, Proceedings of the All-Ukrainian Scientific and Practical Conference]. Kyiv [in Ukrainian].

8. Rusliakova, E., Timofeeva, E., Shestakova, Iu., \& Chepaikin, D. (2020). Issledovanie urovnia empatii $\mathrm{u}$ podrostkov, uvlechennykh kompiuternymi tekhnologiiami. Tcifrovaia empatiia [The study of the level of empathy among adolescents who are keen on computer technology. Digital empathy]. Mir nauki. Pedagogika i psikhologiia, 6. Retrieved from https://mir-nauki.com/PDF/20PSMN620.pdf [in Russian].

9. Starichenko, B. (2013). Metodika ispolzovaniia informatcionno-kommunikatcionnykh tekhnologii $\mathrm{v}$ uchebnom protcesse [Methodology for using information and communication technologies in the educational process]. In Kontceptualnye osnovy kompiuternoi didaktiki [Conceptual foundations of computer didactics]. Ekaterinburg: Ural. gos. ped. un-t. [in Russian].

10. Umnov, S. Zachem uspeshnomu cheloveku nuzhen digital-intellekt [Why does a successful person need digital intelligence]. Retrieved from https://www.vedomosti.ru/management/articles/2014/07/16/ intellekt-novejshego-vremeni [in Russian].

11. Tcifrovaia pamiat [Digital memory]. Material iz Vikipedii - svobodnoi entciklopedii [From Wikipedia, the free encyclopedia]. Retrieved from https://ru.wikipedia.org/wiki/\%D0\%A6\% D0\%B8\%D1\%84\%D1\%80\%D0\%BE\%D0\%B2\%D0\%B0\%D1\%8F \%D0\%BF\%D0\%B0\%D0\%BC\%D1\%8F \%D1\%82\%D1\%8C\#: :text=\%D0\%A6\%D0\%B8\%D1\%84\%D1\%80\%D0\%BE\%D0\%B2\%D0\%B0\%D1\%8F \%20\%D0\%BF\%D0\%B0\%D0\%BC\%D1\%8F\%D1\%82\%D1\%8C\%20(\%D0\%B0\%D0\%BD\%D0\%B3\%D0\% BB. $\%$ D0\%B6\%D0\%B8\%D0\%B7\%D0\%BD\%D0\%B8\%2C\%20\%D1\%82\%D0\%B0\%D0\%BA\%20\%D0\%B8 \%20\%D0\%BF\%D0\%BE\%D1\%81\%D0\%BB\%D0\%B5\%20\%D0\%BD\%D0\%B5\%D0\%B5. [in Russian].

12. Tcifrovoi intellekt: 8 digital-navykov, kotorye prigodiatsia sovremennomu pokoleniiu detei [Digital intelligence: 8 digital skills that will be useful for the modern generation of children]. Retrieved from https://womo.ua/tsifrovoy-intellekt-8-digital-navyikov-kotoryie-prigodyatsya-sovremennomupokoleniyu-detey/ [in Russian].

13. Iak vyiavliaty empatiiu $\mathrm{v}$ navchalnomu onlain-seredovyshchi [How to show empathy in the online learning environment]. Retrieved from http://osnova.com.ua/news/1903\%D0\%AF\%D0\%BA \%D0\%B2\%D0\%B8\%D1\%8F\%D0\%B2\%D0\%BB\%D1\%8F\%D1\%82\%D0\%B8 \%D0 \%B5\%D0\%BC\%D0\%BF\%D0\%B0\%D1\%82\%D1\%96\%D1\%8E \%D0\%B2 \%D0\%BD\%D0\%B0\%D0\%B2 \%D1\%87\%D0\%B0\%D0\%BB\%D1\%8C\%D0\%BD\%D0\%BE\%D0\%BC\%D1\%83 \%D0\%BE\%D0\%BD\%D0 \%BB\%D0\%B0\%D0\%B9\%D0\%BD-\%D1\%81\%D0\%B5\%D1\%80\%D0\%B5\%D0\%B4\%D0\%BE\%D0\%B2\% D0\%B8\%D1\%89\%D1\%96\%3F [in Ukrainian].

14. Bogdanova, D. \& Berezina, N. (2014). Opyt transformatcii tcifrovoi i mediagramotnosti: na puti $\mathrm{k}$ tcifrovoi gramotnosti [The experience of digital and media literacy: on the path to digital citizenship], Konferentsiya IITE2014, materialy konferentsii [IITE2014 Conference, Proceedings of the Conference]. Moscow [in Russian].

15. DQ Institute. Leading Digital Education, Culture and Innovation. Retrieved from https://www.dqinstitute.org/ [in English]. 
Kokhanovska O.V., orcid.org/0000-0001-7294-173X

Slyusarenko N. V.,

ESSENCE AND COMPONENTS OF DIGITAL PERSONAL INTELLIGENCE

orcid.org/0000-0002-9215-5936

The article highlights the essence of the components of digital personal intelligence, which largely determines the effectiveness of human activity in the modern world.

It is noted that digital intelligence in humans today is a necessity, as modern learning models will become effective only if there is a sufficient level of mastery of digital technologies by all participants in the educational process, the ability to build effective relationships in the digital space. The essence of digital intelligence (DQ), its components (digital memory, digital empathy and digital footprint) and their place in the modern educational environment have been represented. It is emphasized that the process of digitalization of society directly affects the set of competencies that are necessary for a modern specialist. This set of competencies is changing dynamically in parallel with changes in the economy.

The concept of digital empathy and its significance in the organization of the educational process in the context of online learning have been revealed. It is indicated that the manifestation of empathy in the online environment is more complex than in face-to-face communication.

Some strategies that help the speaker to evoke emotions are described: feeling and understanding of the target audience, instructing students to master the material, colours, emotions, words, maintaining regular online communication, chatting and active listening.

It is emphasized that the concept of digital emotional memory is associated with digital empathy, as the mastery of information and digital technologies is accompanied by a significant emotional colour. The concept of "digital footprint" is revealed as information that remains as a result of the user's work in the network, as well as "digital memories", which are based on emotional contact with digital objects and enhance learning motivation by creating a situation of success.

It is concluded that in the context of global digitalization of the modern world, the presence of advanced digital intelligence and its components is a necessity for each individual, and the general formula of a modern successful personality is a harmonious combination of cognitive, emotional and digital intelligences.

Key words: digital personality intelligence, digital memory, digital empathy, digital footprint, digital competencies, digitalization of education.

Дата надходження статті: 15.10.2020 p. Рецензент: доктор педагогічних наук, доцент Рябуха I.М.

УДК 371.11:351.712.2.025

DOI https://doi.org/10.37915/pa.vi46.107

Івасів О. В.,

orcid.org/0000-0002-6790-9281

\section{АЯГОРИТМІЗАЦІЯ РОЗРОБКИ КРИТЕРІЇВ ОЦІНЮВАННЯ ПРОЕКТНОї ДІЯЛЬНОСТІ}

Стаття присвячена проблемах оцінювання дієвості проєктної діяльності на основи критеріального підходу. Актуальність піднятої проблеми зумовлена потребою мінілізаціӥ суб'єктивного підходу в оцінюванні проєктної діяльності. Метою статті є аналіз теоретичних напрацъювань із проблеми сутності критеріального оцінювання, побудова алгоритму оцінювання дієвості проєктної діяльності та дослідження рівня дієвості проєктної діяльності за допомогою параметрично-показникової модехі оццінювання. Аналіз понятійного апарату, пов'язаного

*C) Івасів O. B.

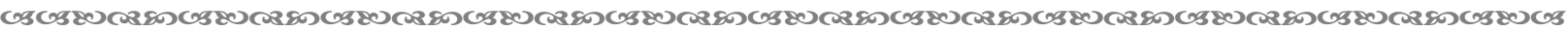

